\title{
Alcoholic lung injury: pineapple peel extract modulates antioxidant enzymes and attenuates lipid peroxidation in rat models
}

\author{
Ochuko L. Erukainure $1^{*}$, John A. Ajiboye 2 , Oluwatoyin Y. Okafor ${ }^{3}$, Emeka E. Okoro $^{4}$, Godfrey Asieba ${ }^{5}$,
} Bolanle B. Sarumi', Sunday O. Adenekan ${ }^{6}$ and Moses Z. Zaruwa ${ }^{7}$

\begin{abstract}
Background: The therapeutic potentials of the methanolic extract of pineapple peel against alcohol - induced lung injury in male albino rats was investigated. GC - MS was used in characterizing secondary metabolites of the extracts.

Methods: Oxidative stress was induced by oral administration of ethanol $(20 \% \mathrm{~W} / \mathrm{v})$ at a dosage of $5 \mathrm{~mL} / \mathrm{kg}$ body weight in rats. After 28 days of treatment, the rats were fasted overnight and sacrificed by cervical dislocation. Lung tissue homogenates were used for the assessment of protein concentration, reduced glutathione (GSH), catalase, superoxide dismutase (SOD) and lipid peroxidation.

Results: GCMS analysis revealed the presence of 10 compounds with ethanimidic acid, ethyl ester (32.52\%) being the most predominant compound. Ingestion of alcohol led to a significant $(p<0.05)$ reduction in GSH, malondialdehyde (MDA) and protein levels in the lung tissues, this was significantly reversed on treatment with the extract. Ingestion also led to increased significant $(p<0.05)$ SOD and catalase activity respectively. This was significantly $(p<0.05)$ reduced on treatment with the extract.

Conclusion: These results insinuate the therapeutic potential of the extract against alcoholic oxidative damages in lungs. The identified compounds may influence free radical scavenging and arrest of lipid peroxidation, thereby restoring redox homeostasis.
\end{abstract}

Keywords: Alcohol, Lung injury, Oxidative stress, Pineapple peel

\section{Background}

Oxidative stress has been described as a major facet of alcohol induced tissue injury and machinery in alcoholic lung disease as well as other diseases [1-3]. $\mathrm{H}_{2} \mathrm{O}_{2}$ produced during alcohol metabolism to acetaldehyde by cytochrome P450-2E1 (CYP2E1) in both liver and lungs interacts with copper/iron leading to generation of Reactive Oxygen Species (ROS) and/or its products [4,5]. Oxidative stress sets in when there is an imbalance between oxidant (ROS) production and the system's ability to detoxify it in favour of the oxidants.

\footnotetext{
* Correspondence: loreks@yahoo.co.uk

${ }^{1}$ Nutrition and Toxicology Division, Federal Institute of Industrial Research, Oshodi, Lagos, Nigeria

Full list of author information is available at the end of the article
}

The medicinal properties of plants especially its antioxidant role against most ROS induced injuries are well documented [6,7]. These properties have been attributed to their phytochemical constituents with much emphasis on flavones, isoflavones, flavonoids, anthocyanin, coumarin lignans, catechins and isocatechins owing to their well studied antioxidant activities [6].

Over the years, pineapple (Ananas cosmosus) peels have been an important ingredient in ethno medicine. They have been used traditionally in the treatment and management of various ailments. Erukainure et al. [8, 9] reported its protective effect against alcohol - induced brain and splenic injuries. A relationship between antioxidant activity, $\beta$-glucosidase and total phenolic content in pineapple peel/soy flour extracts has been reported [10]. Wood [11] 
reported that it is rich in antioxidants such as flavonoids and vitamins $\mathrm{A}$ and $\mathrm{C}$.

This paper aims at investigating the therapeutic potentials of the methanolic extract of pineapple peel against alcohol - induced lung injury in male albino rats as well as characterize its secondary metabolites using Gas Chromatography Mass Spectrometer (GC - MS).

\section{Methods}

\section{Plant materials}

Pineapple peels were collected from a local fruit seller at Oshodi, Lagos, Nigeria. They were sorted and rinsed to remove dirt. They were air-dried and grounded to fine texture with a laboratory mill. The blended peels were subjected to methanolic extraction 8-10 h using a soxhlet extractor. The extract was concentrated and then stored for subsequent use.

\section{Gas chromatography-mass spectrometry (GCMS) instrumentation}

The extract was also subjected to GC - MS analysis to identify the secondary metabolites likely present.

\section{GC}

Shimadzu GC-MS QP2010 ULTRA with column: Optima 5MS (5\% diphenyl $95 \%$ dimetylpolysiloxane); length: $30 \mathrm{~m}$; thickness: $0.25 \mu \mathrm{m}$; ID: $0.25 \mathrm{~mm}$; Column flow: $1.34 \mathrm{ml} / \mathrm{min}$ Gas: helium. Column flow was set at $1.34 \mathrm{ml} /$ min and temperature of column maintained at $60{ }^{\circ} \mathrm{C}$ for 2 min and then raised to $200{ }^{\circ} \mathrm{C}\left(15{ }^{\circ} \mathrm{C} / \mathrm{min}\right)$ followed by $9 \mathrm{~min}$ at $280{ }^{\circ} \mathrm{C}\left(5^{\circ} \mathrm{C} / \mathrm{min}\right)$.

\section{GC - MS}

The National Institute of Standards and Technology (NIST) mass spectral program 2011 was used for mass spectral survey. The concentrations of the identified compounds were calculated using area normalization over flame ionization detector response method.

\section{Animals}

Thirty male albino rats weighing 90-120 g were used for the present investigation. They were reared at the Animal House of the Biochemistry Department of Bells University of Technology, Ota, Nigeria.

They were acclimatized for 2 weeks on pelletized mouse chow before the commencement of the experiment. Water was given ad libitum at room temperature with a 12-h light and dark cycle. The rats were divided into six groups, each consisting of five animals as shown below:

Group 1: Distilled water only ( $5 \mathrm{~mL} / \mathrm{kg}$ body weight

[bw]) (control)

Group 2: Ethanol only (negative control)

Group 3: Ethanol + Pineapple peel extract (250 mg/kg bw)
Group 4: Ethanol + Pineapple peel extract (500 mg/kg bw) Group 5: Pineapple peel extract only (500 mg/kg bw)

Group 6: Ethanol + Distilled water $(5 \mathrm{~mL} / \mathrm{kg} \mathrm{bw})$

Oxidative stress was induced by oral administration (intubation) of ethanol $(20 \% \mathrm{w} / \mathrm{v})$ at a dose of $500 \mathrm{mg} / \mathrm{kg}$ bw. Pineapple extracts were administered $30 \mathrm{~min}$ after alcohol administration on daily basis via intubation. The dose of ethanol, pineapple peel extract and the period of treatment were selected on the basis of previous studies by Faremi et al. [12] and Erukainure et al. [8]. The animals used in the present study were maintained in accordance with the approval of the Animal Ethical Committee, Bells University of Technology, Ota, Nigeria.

After 28 days of treatment, the rats were fasted overnight and sacrificed by cervical dislocation.

\section{Preparation of tissue homogenates}

The lungs were removed, rinsed in the ice-cold $1.15 \% \mathrm{KCl}$ solution to wash off excess blood, blotted dried with filter paper and weighed. They organs were homogenized and centrifuged at 10,000 rpm for $15 \mathrm{~min}$ in an ultracentrifuge at a temperature of $-2{ }^{\circ} \mathrm{C}$ to get the mitochondrial fraction. The supernatant was decanted and stored at $-4{ }^{\circ} \mathrm{C}$ for subsequent analysis. Each time the supernatant was outside the freezer, it was kept in ice bags.

Lowry's method was used in the determination of tissue proteins using bovine serum albumin (BSA) as standard [13].

\section{Determination of oxidative stress parameters}

Reduced glutathione (GSH) activity was determined according to the method of Ellman [14]. Lipid peroxidation was determined by measuring malondialdehyde (MDA) formed by thiobarbituric acid reaction (TBAR) as described by Chowdhury and Soulsby [15]. Catalase

Table 1 Identified compounds of the pineapple extract

\begin{tabular}{lcrl}
\hline Peak no. & Retention time (min) & Area \% & Compounds \\
\hline 1 & 3.47 & 32.52 & Ethanimidic acid, ethyl ester \\
2 & 5.46 & 13.73 & Oxalic acid, butyl propyl ester \\
3 & 8.25 & 7.20 & $\begin{array}{l}\text { Acetamide, N,N'-ethylenebis } \\
\text { (N-nitro- }\end{array}$ \\
4 & 8.54 & 1.15 & Glycidol \\
5 & 9.96 & 4.37 & $\begin{array}{l}\text { Pyrimidine-2,4(1H,3H)-dione, } \\
5\end{array}$ \\
6 & 10.42 & 13.70 & Propane \\
7 & 13.41 & 12.86 & 4-Hepten-3-one, 4-methyl- \\
8 & 21.49 & 5.90 & Di-tert-butyl peroxide \\
9 & 26.35 & 6.62 & Pyributicarb \\
10 & 27.64 & 1.95 & Carbamic acid, monoammon \\
\hline
\end{tabular}


(CAT) activity was estimated by measuring the rate of decomposition of $\mathrm{H}_{2} \mathrm{O}_{2}$ [16]. The method described by Misra and Fridovich [17] was adopted in determining level of superoxide dismutase (SOD) activity.

\section{Statistical analysis}

To address the biological variability, each set of experiments was repeated at least three times. Differences between the groups were analysed by one-way analysis of variance (ANOVA) with the aid of SPSS software (SPSS
Inc., Chicago, IL, USA) standard version 17. The $p$ values of $<0.05$ were considered statistically significant for differences in mean using the least of significant difference. Data were reported as mean \pm standard deviation (SD).

\section{Results}

GCMS analysis of the methanolic extract revealed the presence of 10 compounds as shown in Table 1 and Fig. 1. Ethanimidic acid, ethyl ester (32.52 \%) was observed to be the most predominant compound, this was followed

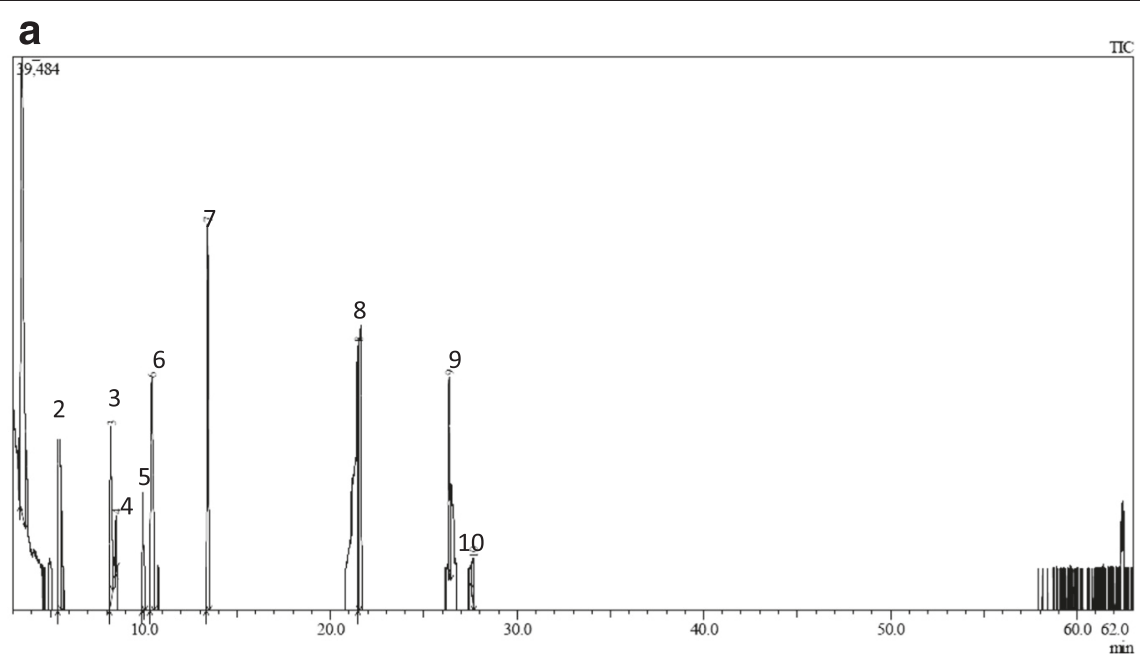

b

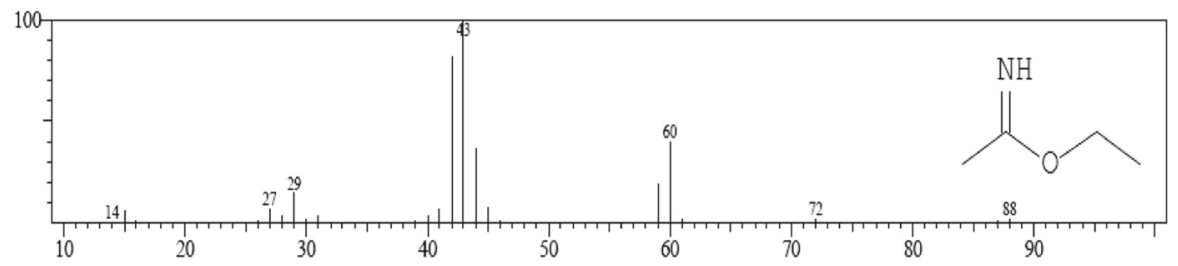

C

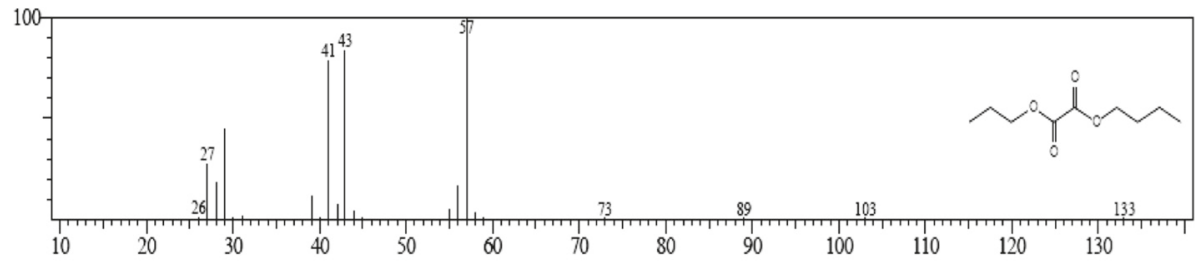

d

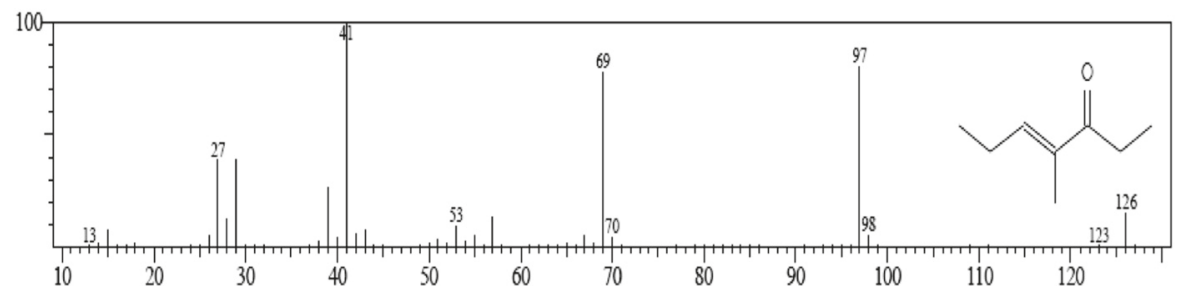

Fig. 1 a GCMS Chromatogram of pineapple peel methanolic extract; b MS of Ethanimidic acid, ethyl ester; c MS of Oxalic acid, butyl propyl ester; d MS of 4-Hepten-3-one, 4-methyl- 
by oxalic acid butyl propyl ester (13.73 \%), Propane (13.70 \%) and 4-Hepten-3-one, 4-methyl- (12.86 \%) respectively. Carbamic acid, monoammon (1.95\%) and Glycidol (1.15\%) had the least concentrations.

Ingestion of alcohol led to a significant $(p<0.05)$ reduction in the GSH levels in the lung tissues (group 2) as depicted in Fig. 2. An increased level was observed on treatment with the extract at both single $(250 \mathrm{mg} / \mathrm{kg} \mathrm{bw})$ and double doses $(500 \mathrm{mg} / \mathrm{kg} \mathrm{bw})$. Much higher levels were observed when the extract was administered to normal albino rats (group 5) and distilled water to ethanol treated rat albino rats (group 6).

An increased significant $(p<0.05)$ SOD and catalase activity on ingestion of alcohol when compared to the control (group) as shown in Figs. 3 and 4 respectively. This was significantly $(p<0.05)$ reduced on treatment with the extracts at both doses. A significant reduced activity was also observed on treatment with distill water.

Significant increased $(p<0.05)$ level of MDA was observed in the alcohol - only treated group indicating an occurrence of lipid peroxidation on alcohol ingesttion (Fig. 5). This was significantly $(p<0.05)$ reduced on treatment with the extracts at both doses. Treatment with distilled water also led to increased MDA level.

Alcohol ingestion led to significant reduction in tissue protein concentration as depicted in Fig. 6. Treatment with the extract led to a significant $(p<0.05)$ increase, with the single dose showing the highest concentration.

\section{Discussion}

A substantial dose of alcohol ingested has been reported to reach the airway passages by the bronchial circulation directly through the ciliated epithelium and metabolized by oxidative and/or nonoxidative pathways [2,3]. This is usually excreted in exhaled breath but local metabolism within the lungs has been shown to cause an altered redox status with increased ROS production leading to oxidative injury $[2,3,18]$. In this study, oxidative injury was induced in rat lungs by alcohol and treated with pineapple peel methanolic extract.

The observed reduced GSH level in the alcohol - only treated group indicates an occurrence of oxidative stress. GSH is a major endogenous antioxidant, which counteracts free-radical-mediated damage and a major determining factor in alcoholic lung disease [19]. Reduced GSH level has been reported in chronic alcohol ingestion within the alveolar space, leading to an impairment of alveolar immunity and thus increasing the lung susceptibility to oxidant-mediated injury [3]. The observed increased level in the extract - treated rats insinuates a therapeutic potential of the pineapple peel against alcoholic lung disease. Erukainure et al. [8,9] reported similar observations in brain and splenic tissues of alcohol - ingested rats. The increased activity of the extract in normal rats further portrays an antioxidant activity of the pineapple peels.

SOD is the first of the scavenger enzyme series to ameliorate the oxidative damage [20]. It catalyzes the dismutation of superoxide anion $\left(\mathrm{O}_{2}{ }^{\bullet-}\right)$ to form hydrogen peroxide $\left(\mathrm{H}_{2} \mathrm{O}_{2}\right)$. This is rapidly decomposed to water $\left(\mathrm{H}_{2} \mathrm{O}\right)$ and oxygen $\left(\mathrm{O}_{2}\right)$, a reaction catalyzed by catalase. The observed increased activities of SOD and catalase in the alcohol - only treated group contradicts Das and Mukherjee [2] who reported decreased activities in alcoholic lung injury. Rahman and MacNee [21] however, reported an induction of SOD and catalase enzymes in response to oxidative stress. Their increased activity may thus be attributed to induction of oxidative stress. Their significant $(p<0.05)$ reduction on treatment with pineapple peel extract is an indication of the antioxidant potentials of the extract.

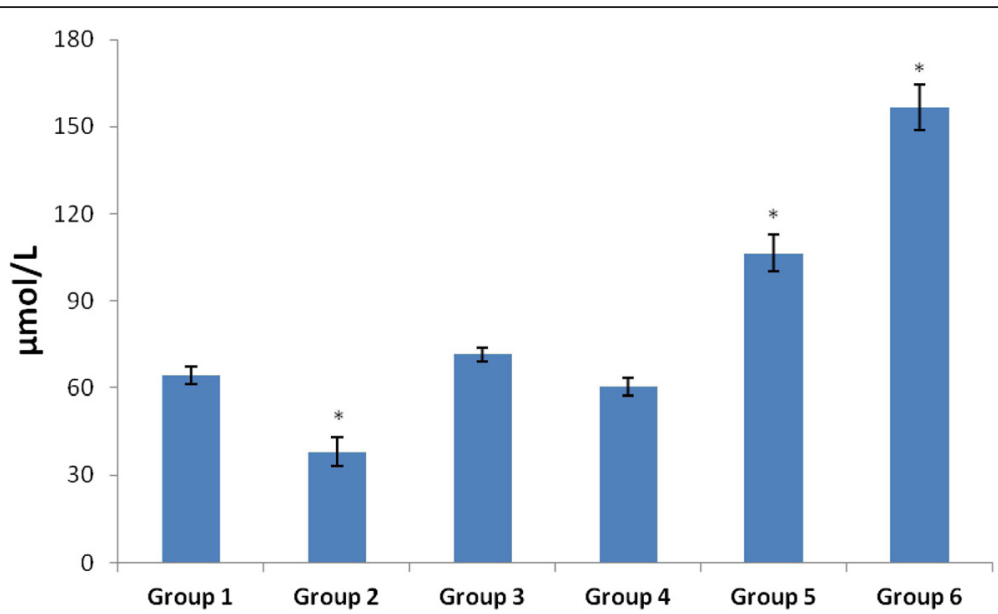

Fig. 2 GSH activities of experimental groups. Values = mean $\pm S D ; n=6$. ${ }^{*}$ statistically significant $(p<0.05)$. Legend: Group 1: Distilled water only $(5 \mathrm{~mL} / \mathrm{kg} \mathrm{bw})$; Group 2: Ethanol only; Group 3: Ethanol + Pineapple peel extract ( $250 \mathrm{mg} / \mathrm{kg}$ bw); Group 4: Ethanol + Pineapple peel extract (500 mg/kg bw); Group 5: Pineapple peel extract only (500 mg/kg bw); Group 6: Ethanol + Distilled water (5 mL/kg bw) 


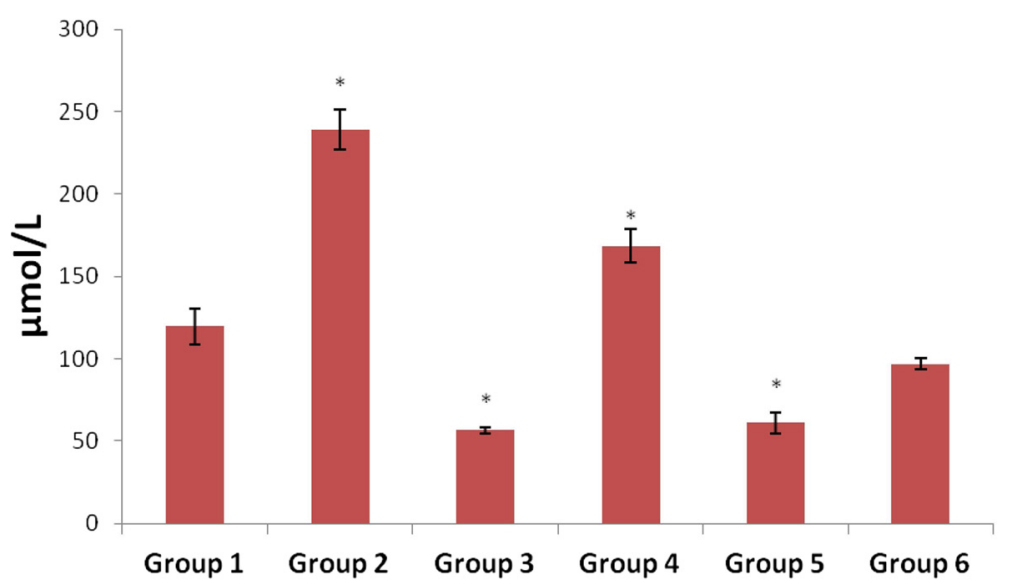

Fig. $3 \mathrm{SOD}$ activities of experimental groups. Values = mean $\pm \mathrm{SD} ; n=6$. ${ }^{*}$ statistically significant $(p<0.05)$. Legend: Group 1: Distilled water only ( $5 \mathrm{~mL} / \mathrm{kg} \mathrm{bw}$ ); Group 2: Ethanol only; Group 3: Ethanol + Pineapple peel extract (250 mg/kg bw); Group 4: Ethanol + Pineapple peel extract (500 mg/kg bw); Group 5: Pineapple peel extract only (500 mg/kg bw); Group 6: Ethanol + Distilled water (5 mL/kg bw)

Alcohol induced toxicity have been linked with increased oxidation of proteins and lipids to form oxidized proteins and peroxide products, malondialdehyde (MDA) and acetaldehyde (MAA)-adducted proteins [22]. The increased MDA level and reduced protein concentration in the alcohol - only treated group (Figs. 5 and 6) indicates an occurrence of oxidative stress. Lipid peroxidation has been shown to alter membrane integrity, disrupting normal signaling events required for homeostasis and cause cell injury [3]. The observed significant $(p<0.05)$ reversal on treatment with pineapple peel extract further portrays the antioxidant protective potential of the extract against alcohol - induced oxidative damage in lungs.

The observed reduced antioxidant activity with increasing concentration of the extract can be attributed to exacerbation of alcoholic injury by the extract at higher concentrations. This corresponds to previous studies by Erukainure et al. $[8,9]$. This may also be attributed to the observed compounds of the extracts. Though the extract showed no toxicity in normal rats at higher dose, the use of lower concentration in the treatment of alcoholic injury is however recommended.

In this study, administration of water was observed to exhibit similar effects as the pineapple peel extract. Water is well a known detoxicant and have been used over the years in detoxifying drug and alcohol overdose. Thus, may explain the increased antioxidant activities in group 6. Moreover, the concentration of alcohol decreases with increased dilution with water thereby reducing its toxic effect. This is of tremendous advantage as it readily available and cheap. To the best of our knowledge, this is the first time the protective potential of water against alcoholic lung oxidative injury is being reported.

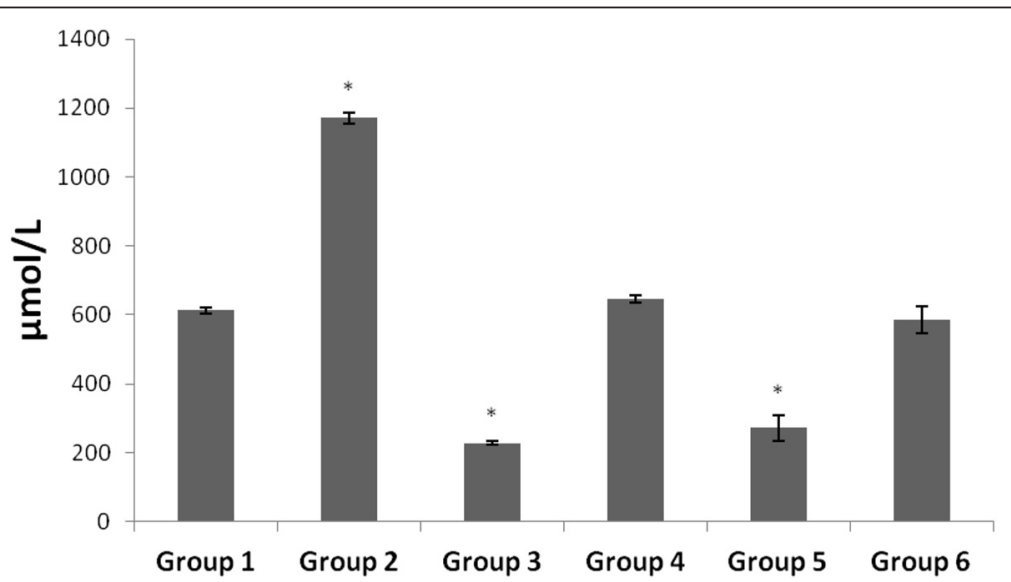

Fig. 4 Catalase activities of experimental groups. Values $=$ mean $\pm S D ; n=6$. *statistically significant $(p<0.05)$. Legend: Group 1: Distilled water only (5 mL/kg bw); Group 2: Ethanol only; Group 3: Ethanol + Pineapple peel extract ( $250 \mathrm{mg} / \mathrm{kg}$ bw); Group 4: Ethanol + Pineapple peel extract (500 mg/kg bw); Group 5: Pineapple peel extract only (500 mg/kg bw); Group 6: Ethanol + Distilled water (5 mL/kg bw) 


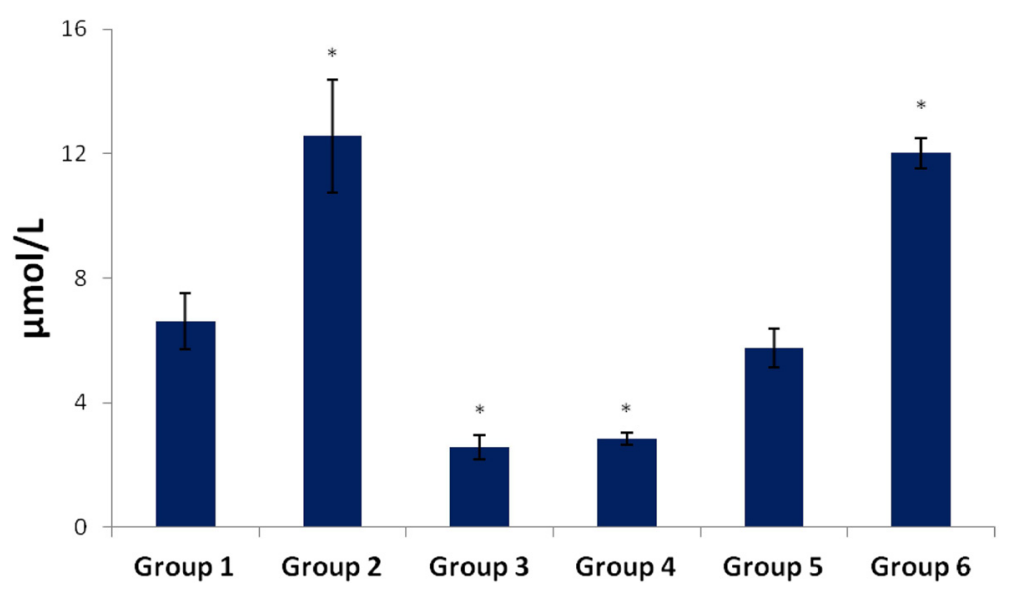

Fig. $5 \mathrm{MDA}$ levels of experimental groups. Values = mean $\pm \mathrm{SD} ; n=6$. ${ }^{*}$ statistically significant $(p<0.05)$. Legend: Group 1: Distilled water only $(5 \mathrm{~mL} / \mathrm{kg}$ bw); Group 2: Ethanol only; Group 3: Ethanol + Pineapple peel extract ( $250 \mathrm{mg} / \mathrm{kg}$ bw); Group 4: Ethanol + Pineapple peel extract (500 mg/kg bw); Group 5: Pineapple peel extract only (500 mg/kg bw); Group 6: Ethanol + Distilled water (5 mL/kg bw)

These observed anti - oxidative stress effects may reflect a synergetic activity of the identified compounds present in the extract (Fig. 1 and Table 1). The scavenging properties of most amide esters have been documented to be greatly influence by the presence of hydrogen donating group [23]. This depicts the antioxidant potentials of ethanimidic acid, ethyl ester. Oxalic acid is often reported as an antinutrient owing to its chelating of divalent cations especially magnesium and calcium to form crystals. However, its ability to chelate iron (II) $\left(\mathrm{Fe}_{2}^{+}\right)$is of great importance as it reduces the availability of $\mathrm{Fe}_{2}^{+}$ for oxidation by $\mathrm{H}_{2} \mathrm{O}_{2}$ to generate the highly reactive hydroxyl radicals (Fenton reaction). Oxalic acid, butyl propyl ester may thus exhibit antioxidant properties by chelating $\mathrm{Fe}_{2}^{+}$, which explains the observed reduced MDA levels (Fig. 5). 4-Hepten-3-one, 4-methyl- has been recognized as a ketone. The protective properties of ketones against free radicals and lipid peroxidation in vitro has been reported [24].

\section{Conclusion}

These results insinuate the therapeutic potential of the methanolic extract of pineapple peel against alcoholic oxidative damages in lungs. This effect can be attributed to the identified compounds of the extracts which may influence free radical scavenging and arrest of lipid peroxidation, thereby restoring redox homeostasis. However, there is need to isolate these compounds and their biological activity against alcoholic lung injury ascertained in vitro and in vivo. There is also need for further investigations on the protective effect of water against alcoholic lung injury, as it is readily available and much cheaper. Further studies

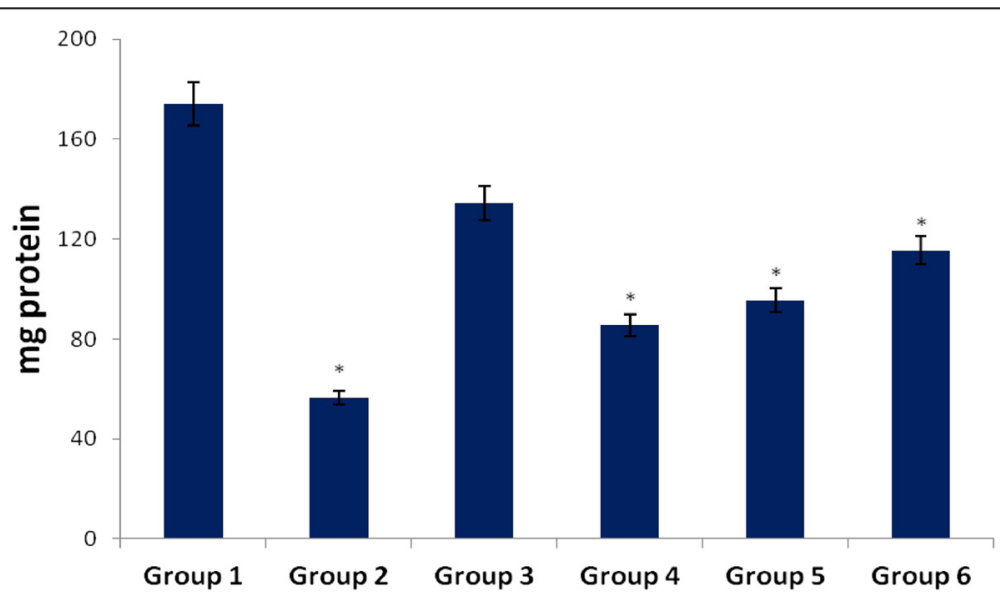

Fig. 6 Protein levels of experimental groups. Values $=$ mean $\pm S D ; n=6$. * statistically significant $(p<0.05)$. Legend: Group 1: Distilled water only $(5 \mathrm{~mL} / \mathrm{kg} \mathrm{bw})$; Group 2: Ethanol only; Group 3: Ethanol + Pineapple peel extract ( $250 \mathrm{mg} / \mathrm{kg}$ bw); Group 4: Ethanol + Pineapple peel extract (500 mg/kg bw); Group 5: Pineapple peel extract only (500 mg/kg bw); Group 6: Ethanol + Distilled water (5 mL/kg bw) 
are also advised on the histology and immunochemistry of the treated lung tissues.

\section{Competing interests}

Ochuko L. Erukainure, John A. Ajiboye, Oluwatoyin Y. Okafor, Emeka E. Okoro, Godfrey Asieba, Bolanle B. Sarumi, Sunday O. Adenekan and Moses Z. Zaruwa declare that they have no competing interests.

\section{Authors' contributions}

OLE, JAA, OYO and EEO conceived the project. GA and SOA carried out the GCMS analysis. OLE, JAA, BBS, and MZZ designed the experiment. All authors except MZZ were involved in the animal trials and analysis. OLE and JAA wrote the manuscript. All authors read and approved the manuscript.

\section{Author details}

'Nutrition and Toxicology Division, Federal Institute of Industrial Research, Oshodi, Lagos, Nigeria. ${ }^{2}$ College of Natural and Applied Sciences, Bells University of Technology, Ota, Nigeria. ${ }^{3}$ Department of Natural Sciences, Albany State University, Albany, GA, USA. ${ }^{4}$ College of Health and Sciences, Adventist University of West Africa, Monrovia, Liberia. ${ }^{5}$ Analytical Division, Federal Institute of Industrial Research, Lagos, Nigeria. ${ }^{6}$ Department of Biochemistry, University of Lagos, Lagos, Nigeria. ${ }^{7}$ Department of Chemistry, Adamawa State University, Mubi, Nigeria.

Received: 30 October 2015 Accepted: 1 June 2016

Published online: 29 June 2016

\section{References}

1. Heffner JE, Repine JE. Pulmonary strategies of antioxidant defense. Am Rev Respir Dis. 1989;140:531-54.

2. Das SK, Mukherjee S. Long-term ethanol consumption leads to lung tissue oxidative stress and injury. Oxid Med Cell Longev. 2010;3(6):414-20.

3. Kaphalia L, Calhoun WJ. Alcoholic lung injury: metabolic, biochemical and immunological aspects. Toxicol Lett. 2013;222:171-9.

4. Yin SJ, Liao CS, Chen CM, Fan FT, Lee SC. Genetic polymorphism and activities of human lung alcohol and aldehyde dehydrogenases: implications for ethanol metabolism and cytotoxicity. Biochem Genet. 1992;30:203-15.

5. Haoraha J, Ramirez SH, Floreani N, Gorantla S, Morsey B, Persidsky Y. Mechanism of alcohol-induced oxidative stress and neuronal injury. Free Radic Biol Med. 2008:45(11):1542-50.

6. Aqil F, Ahmed I, Mehmood Z. Antioxidant and free radical scavenging properties of twelve traditionally used Indian medicinal plants. Turk J Biol. 2006;30:177-83.

7. Abovwe JA, Erukainure OL, Oke OV, Okafor OY, Ajiboye AJ. Modulatory effects of Globimetula Braunii on lipid peroxidation and antioxidant status in hypercholesteremic rats. Inventi Rapid: Ethnopharmacol. 2010; ep25.

8. Erukainure OL, Ajiboye JA, Adejobi RO, Okafor OY, Adenekan SO. Protective effect of pineapple (Ananas cosmosus) peel extract on alcohol-induced oxidative stress in brain tissues of male albino rats. Asian Pac J Trop Dis. 2011;1(1):5-9.

9. Erukainure OL, Ajiboye JA, Okafor OY, Kosoko SB, Owolabi FO, Adenekan SO. Antioxidant effect of pineapple (Ananas cosmosus) peel extract on alcoholinduced oxidative stress in splenic tissues of male albino rats. J Food Biochem. 2012;36:643-7

10. Correia RTP, Mccue P, Vattem DA, Magalhães MMA, Macêdo GR, Shetty K. Amylase and helicobacter pylori inhibition by phenolic extracts of pineapple wastes bioprocessed by rhizopus oligosporus. J Food Biochem. 2004;28(5): 419-34.

11. Wood R. The whole foods encyclopedia. New York: Prentice-Hall Press; 1988.

12. Faremi TY, Suru SM, Fafunso MA, Obioha UE. Hepatoprotective potentials of Phyllanthus amarus against ethanol-induced oxidative stress in rats. Food Chem Toxicol. 2008;46(8):2658-64.

13. Lowry OH, Rosebrough NJ, Farr AL, Randall RJ. Protein measurement with folin-phenol reagent. J Biol Chem. 1951;193:265-75.

14. Ellman GL. Tissue sulfhydryl groups. Arch Biochem Biophys. 1959:82:70-7.

15. Chowdhury P, Soulsby M. Lipid peroxidation in rat brain is increased by simulated weightlessness and decreased by a soy-protein diet. Ann Clin Lab Sci. 2002:32(2):188-92

16. Aebi HE. Methods in enzymatic analysis. New York: Academic; 1983.
17. Misra H, Fridovich I. The role of superoxide anion in the autooxidation of epinephrine and a simple assay for Superoxide Dismutase. J Biol Chem. 1972;247:3170

18. Moss M, Guidot DM, Wong-Lambertina M, Ten HT, Perez RL, Brown LAS. The effects of chronic alcohol abuse on pulmonary glutathione homeostasis. Am J Resp Crit Care Med. 2000;161:414-9.

19. Guidot DM, Roman J. Chronic ethanol ingestion increases susceptibility to acute lung injury-role of oxidative stress and tissue remodeling. Chest. 2002:122:3095-14

20. Thenmozhi AJ, Subramanian P. Antioxidant potential of Momordica charantia in ammonium chloride-induced hyperammonemic rats. Evid Complemt Alter Med. 2011; http://dx.doi.org/10.1093/ecam/nep227.

21. Rahman I, MacNee W. Lung glutathione and oxidative stress: implications in cigarette smoking-induced airway disease. Am J Physiol. 1999;277:1067-88.

22. Tuma DJ, Casey CA. Dangerous byproducts of alcohol breakdown-focus on adducts. Alcohol Res Health. 2003;27(4):285-90.

23. Son S, Lewis BA. Free radical scavenging and antioxidative activity of caffeic acid amide and ester analogues: structure-activity relationship. J Agric Food Chem. 2002;50(3):468-72.

24. Rajakumar DV, Rao MNA. Antioxidant properties of phenyl styryl ketones. Free Rad Res. 1995;22(4):309-17.

\section{Submit your manuscript to a SpringerOpen ${ }^{\circ}$ journal and benefit from:}

- Convenient online submission

- Rigorous peer review

- Immediate publication on acceptance

- Open access: articles freely available online

- High visibility within the field

- Retaining the copyright to your article

Submit your next manuscript at $>$ springeropen.com 